\title{
Conversaciones crepusculares en torno a la tradición, la cultura popular y la comunicación
}

\section{Conversations at dusk: On tradition, popular culture and communication}

\author{
Luis Díaz Viana y Carmen Morán Rodríguez \\ (Consejo Superior de Investigaciones Científicas-Universidad de Valladolid / \\ Universidad de Valladolid) \\ luis.diaz@cchs.csic.es / carmen.moran@uva.es \\ ORCID ID: 0000-0002-9486-148X / 0000-0002-3074-2414
}

\begin{abstract}
This conversation with Luis Díaz Viana deals about questions such as culture, tradition, globalization, media and social networks nowadays. These topics are tackled by him from a double point of view, but the same approach, as anthropologist and writer.
\end{abstract}

KeYwords: Popular Culture, Cultural Heritage, Globalization, Cultural Appropriation, Luis Díaz Viana
Resumen: Conversación con Luis Díaz Viana en la que se abordan cuestiones acerca de la cultura, la tradición, la globalización y los medios y las redes sociales en los tiempos actuales, desde su doble faceta - indisociable - de antropólogo y de escritor de creación.

Palabras-clave: Cultura popular, Tradición, Globalización, Apropiación cultural, Luis Díaz Viana

Solemos referirnos con crepúsculo a la menguante luz de las últimas horas del día, y metafóricamente al ocaso o final de una etapa. La eclosión de distopías que observamos con solo echar un vistazo a las novedades literarias y audiovisuales que nos aguardan cada semana parecen confirmar que l'esprit du temps es apocalíptico, o más bien postapocalíptico, en lo que tiene todas las trazas de convertirse en una especie de delirio propiciatorio. Pero crepúsculo es también la luz del alba y, en consecuencia, del comienzo de un nuevo día o una nueva época, surgida del final de su predecesora. Esa tesitura - colofón de un tiempo caduco, albor de otro incierto - parece ser hoy la nuestra. Abordamos con Luis Díaz Viana cómo se manifiesta esta pulsión crepuscular en la cultura popular y en la creación. Lo haremos primero desde su perspectiva de investigador en el terreno de la antropología y la filología, y después desde la de creador, novelista, poeta, autor teatral y ensayista.

CARmen Morán Rodríguez. El concepto de tradición es básico tanto en el estudio de la antropología como en el de la literatura, pero parece haber una indefinición del término, o una confusión sobre lo que abarca. Si recurrimos tanto a él es porque sentimos que resulta fundamental, pero a la vez lo aplicamos con sentidos diferentes y a veces contradictorios, lo desdibujamos... Mi propia experiencia al respecto es confusa. Procedo del estudio de la tradición clásica y cuando imparto en Educación Infantil una asignatura llamada «Literatura popular» tengo la impresión de tratar algo distinto... pero el término 
tradición es común, y lo es por algo, de manera que sospecho que en el fondo no hay esa diferencia abismal que a veces transmitimos al contraponer tradición clásica y tradición popular.

Luis Díaz Viana. En efecto. El término tradición es común, y así tiene que ser, porque toda cultura se crea y transmite dentro de una tradición y a través de esa «entrega» de una a otra generación que, etimológicamente, la propia palabra está denotando. Pero me temo que se ha sobrevalorado la importancia del concepto de la tradición en el proceso de creación y transmisión de las culturas identificadas como populares, subalternas o, para decirlo en términos aún más «gramscianos», no hegemónicas; de la misma manera que, como contrapartida, puede haberse exagerado el mérito de la innovación, la originalidad o la vanguardia, especialmente durante los dos últimos siglos, en el ámbito de la literatura tenida como culta. Y, más en general, dentro del panorama de la historia del arte.

C. M. R. El mismo concepto de clásico parece que contiene un componente elitista que, en mi opinión, procede de su modelado en la Ilustración, pero lo cierto es que ante clásicos como Cervantes, Lope de Vega, e incluso atrás en el tiempo, Homero... es mucho lo que hay de popular...

L. D. V. Absolutamente. De hecho, tanto en literatura, como en música o pintura, «clásico» es el término que se ha venido utilizando para definir un cierto tipo de canon entronizado como tal desde las élites intelectuales, políticas y económicas. Lo que ocurre es que las relaciones de la minoría de creadores con «lo popular» nunca han sido las mismas, sino que han ido cambiando según las culturas y las épocas. Por ejemplo, y si pensamos en el ámbito europeo, tales relaciones no funcionaron igual (por intensidad, grado y tipo de contactos) durante la Antigüedad y los siglos medievales que cuando eclosiona el Renacimiento o, más adelante, cuando surge el Romanticismo, que en los periodos Barroco y Neoclásico. En buena medida, y a pesar de que sí ha habido algunas aproximaciones de estudiosos a determinadas épocas con este enfoque, puede decirse que gran parte de esos procesos transformativos, de préstamos, conexión e interinfluencia, están todavía por historiar.

C. M. R. Por todo esto, al tratar de mostrar a los alumnos la diferencia entre la cultura popular y la cultura hegemónica de una manera sencilla, fuerzo la nota eligiendo ejemplos extremos (una pieza de música dodecafónica frente a una rabelada, un poema vanguardista frente a un romance...), pero con malísima conciencia de estar falseando los hechos para que la contraposición teórica y pedagógica se mantenga, y desde luego ofreciendo una visión muy kitsch de la «alta cultura».

L. D. V. Antes te referías a la cercanía (e incluso cabe aventurar que interinfluencia) de autores considerados como «clásicos» para diversos momentos de la humanidad, como Homero en la antigüedad griega o Lope de Vega en nuestros siglos llamados de oro, con lo que se entiende, hoy, como «cultura popular». Y así era. Ni Homero ni Lope estarían, probablemente, muy de acuerdo con las simplificaciones que oponen lo «culto» a lo «popular» como cosas irreconciliables ni entenderían por qué ha llegado a consumarse tal dicotomía. Sobre todo, si tenemos en cuenta que lo más fácil es que, bajo la figura posteriormente construida de un «homero», y con anterioridad a esa invención de las élites aristocráticas de Grecia, hubiera muchos «homeros» a los que podría identificarse como «cantores populares», que es lo que Milman Parry y Albert Lord intentarían demostrar en el siglo pasado con sus estudios de la improvisación y creación oral entre los bardos serbocroatas: lo que se conoce como la teoría de Oral Formula. O si consideramos que Lope de Vega se habría sorprendido de que lo hecho por él fuera mirado después como rareza, anomalía o como plagio. Es decir, que un poeta de éxito masivo, pero igualmente 
consagrado por la corte, «entrara a saco» en un acervo legendario y romancístico que muchos entre su público conocerían y tomara prestado todo lo necesario para edificar un imaginario nacional orgulloso de sí; devolviendo luego, una vez pasadas leyendas y baladas por su ingenio, los mismos relatos a las gentes de que salían hasta mezclarse y perdurar en su memoria. Sin embargo, los recopiladores y estudiosos de la literatura popular, a partir del Romanticismo, se esforzarán en tipificar, precisamente enfatizando lo más singular y pintoresco, las expresiones populares, separándolas de la poesía y literatura cultas, lo que se ha perpetuado hasta ahora.

C. M. R. Tú matizas la opinión de García Canclini cuando afirma que esas manifestaciones de la cultura masiva que él considera "competidoras del folklore» son, en realidad, más bien sus continuadoras en la actualidad, pero sí estás de acuerdo con él en la idea de que existe una presión por desplazar la noción de pueblo y sustituirla por las de popular y popularidad, en una operación de neutralización, de aparente desideologización. Así lo señalas en El regreso de los lobos en 2003. Tengo la impresión de que en los últimos quince años (largos) esto no ha hecho sino incrementarse en muchos niveles, ¿es así?, ¿lo observas en ejemplos cotidianos?

L. D. V. Las culturas que García Canclini entiende como «híbridas» siempre lo fueron. Me parece interesante que García Canclini devuelva a la percepción de lo sucedido con las culturas populares un componente que el folklorismo más nostálgico se esforzó, desde el momento en que comienza el interés de ciertas élites por el «saber del pueblo», en escamotear. Y acerca del cual autores como Henry Glassie ya habían llamado la atención: me refiero a la idea más o menos vaga de «cultura de clase», muy ligada a lo popular, que indica y revela lo que el mismo concepto encierra de manipulaciones y juegos de poder en torno a él. Lo que sí he procurado hacer notar es que hay una continuidad y, en muchas ocasiones, una contigüidad entre los distintos estadios, fases y tradiciones en los procesos de creación y transmisión de las culturas. Que entre esos dos polos de la Great Tradition y la Little Tradition, tal como fueron concebidos por Robert Redfield, caben, en efecto y tal como él señalaba, una infinidad de combinaciones e interconexiones. En este sentido es importante tener presente que lo que en un momento $\mathrm{X}$ fue conceptualizado como «tradicional» por algunos folkloristas y filólogos pasaba antes por «popular» o «vulgar» e incluso podría identificarse con lo que actualmente se considera «cultura de masas». En ese aspecto, la distinción (de matiz) entre lo «popular» y «tradicional» apuntada por Ramón Menéndez Pidal era sin duda lúcida, pero conferir, según se ha hecho más tarde, un carácter casi ontológico o de «sustancialidad» a lo que es una y otra cosa, nos hurta una realidad mucho más compleja, y contraviene lo que en los procesos culturales puede entenderse como un axioma: no hay procesos totalmente irreversibles. Lo que hice en la indagación que dio lugar al libro titulado El regreso de los lobos fue concretamente aplicar lo que había aprendido en mi experiencia previa de varias décadas, al recopilar y estudiar diversas expresiones de la cultura popular, a un campo nuevo para mí y en plena transformación. Con lo que ya sabía, más muchas más preguntas que me hacía al respecto, cambié la dirección del foco: en vez de dirigirlo del presente hacia el pasado lo situé de modo que, centrándome en los cambios que estaban sucediendo (tales la globalización y la circulación del folklore por el ciberespacio), pudiera atisbarse mejor qué realidad y modelo de mundo vendrían luego.

C. M. R. Justamente en El regreso de los lobos ya advertías de un fenómeno como es el de la creación «en vivo y en directo» de estrellas de la televisión a partir de gente percibida como corriente (o incluso por debajo de lo corriente, en un ejercicio catártico que parece subir la autoestima de los espectadores por comparación con esos productos 
televisivos). Desde la fecha de publicación de tu libro (2003), esto se ha incrementado: ya no solo hay Gran Hermano, sino también Gran Hermano VIP, Gandia Shore, Supervivientes, o los talent shows que tienen que ver más con observar en directo las emociones de gente momentáneamente sacada del anonimato que con las disciplinas artísticas. Y lo que es aún más grave: este proceder parece haberse extendido al debate civil en torno a causas sociales y políticas, en una especie de perversión de la democracia. No sé si compartes esto. Pero, por otro lado, parece muy peligroso posicionarse frente a ello sin adoptar una actitud aristocrática (en el peor sentido de la palabra), dogmática... De algún modo, me recuerda a la impresión que los aristoi griegos tuvieron ante la democracia con leyes escritas, que les parecía, curiosamente, tiránica...

L. D. V. El propio Sócrates, quien no tenía reparos ante los usos democráticos, sino al revés, sí mantenía alguna prevención hacia la escritura, a la que tacha de «fármaco de la memoria». Y el caso es que la democracia fue problemática desde el primer momento: la condena de Sócrates o la traición de Alcibíades, un aristócrata destinado a recibir y continuar la «herencia» de Pericles, que va y viene entre persas y griegos intrigando para su provecho, constituyen buenos ejemplos de ello, pudiéndose decir que tan estupendo hallazgo tuvo su primera gran crisis poco tiempo después de que la democracia fuera inventada. Los aristoi, es decir, las élites de entonces, desconfiaban de lo mismo que hace recelar a las de hoy contra todo avance democrático, procurando adelantarse a los acontecimientos y planificar las transformaciones de todo tipo (tecnológicas, económicas, militares) en beneficio propio. En la democracia termina por caber todo (en teoría así debería ser, al menos) y hace que se desdibujen categorías en que los más privilegiados prefieren creer y mantener como inamovibles, además de separadas en el tiempo o el espacio. El mundo actual, en todo caso, resulta bastante paradójico: ese aumento de la democracia o democratización a nivel planetario que algunos auguraban tras el advenimiento de la globalidad, la era «post-tradicional» y más democrática augurada por Anthony Giddens, frecuentemente no está mostrándose como tal. He señalado ya en algunos trabajos que los cambios de esa nueva era están produciendo una triple negación (la sensación de vivir en un no-tiempo, no-espacio, y lugares sin memoria). Lo que estaría acarreando también un desarraigo y desnortamiento creciente, y vuelve a las gentes cada vez más perdidas y manipulables.

C. M. R. Uno de esos debates espectacularizados a los que asistimos en los últimos tiempos es el de la «apropiación cultural», y también es algo que me suscita dudas. Mi respuesta inmediata ante esos linchamientos en las redes sociales sería responder que también los tatuajes, los piercings, son apropiación cultural en los mismos términos, como lo sería el uso del sombrero hongo en Ecuador... y que en definitiva la cultura es un enorme flujo de apropiaciones culturales («Graecia capta...»). Creo en la legitimidad de esa respuesta, pero no se me oculta que la complicidad puede estar acechando en ella...

L. D. V. Esa «espectacularización» es un hecho. Especialmente entre los más jóvenes. Y el flujo de híbridas «apropiaciones» y «reapropiaciones» culturales también. Las revelaciones llevadas a cabo por los trabajos del libro que coordinaron Eric Hobsbawm y Terence Ranger acerca de la «invención de la tradición» constatan que lo «tradicional» es producto de una apropiación continua y de enormes dimensiones. En cuanto a lo «espectacularizada» que se ha tornado la vida de la juventud, no parece tan clara e inequívoca la conclusión (interesadamente tranquilizadora) que escuchamos a menudo de que «la muchachada» viene a hacer, hoy, por otros medios más sofisticados, lo que ha hecho siempre: mandarse fotos, hablar con los amigos, cotillear de chicos y chicas, etc. Ya en esta misma práctica apreciamos algunas innovaciones importantes que el impacto 
globalizador de la vía utilizada provoca sobre el mensaje. No es igual «despellejar» o «ridiculizar» hasta el extremo a un/a adolescente que someterlo a la vergüenza pública y casi cósmica del ciberespacio: de lo primero, se sale con el tiempo y ayuda psicológica; de lo segundo, en muchos casos, no. Y no hay más que echar un vistazo a las inquietantes noticias sobre los suicidios de personas no adultas que se matan por estas causas (más aquellos otros que no salen en los periódicos) para darse cuenta. Pero debe decirse también, ante las muchas voces de alarma al respecto, que el acusar a los más jóvenes de una nueva adicción, la de estar colgados de las pantallas y ordenadores, así como responsabilizarlos enteramente de la misma no es del todo justo. Porque, desde los propios colegios o trámites burocráticos que hay que hacer a cada momento, se les está abocando a esto: es en el ámbito de la educación y la administración donde se tendría que abrir una amplia discusión (con la asunción de culpas correspondiente) para dilucidar si el forzar de modo constante a niños/as, desde muy tiernas edades, a realizar sus trabajos, consultar sus notas, o llevar al día su actividad académica por canales únicamente electrónicos no podría afectar profundamente su futura relación con el ámbito laboral y, algo todavía más grave, su propia comprensión del mundo. Es verdad que todo eso ya existía, que como la cháchara de jovencitos/as nunca cesó, pero su dimensión y consecuencias, al propalarse ahora globalmente, se ha alterado. Y, lo que no ha de ignorarse, el cambio repercute, en varios sentidos, de manera sustancial sobre nuestra existencia. Por supuesto, en lo que toca a la comunicación; especialmente también en lo que atañe a las coordenadas que ya referí antes y que son aquellas con que los humanos nos orientamos en el cosmos: tiempo, lugar y memoria. Ni uno ni otras son ni volverán a ser los mismos. Lo cual, como lo hicieron en su momento la escritura, la imprenta, la electricidad o el teléfono, inaugura una era distinta, transformando irreversiblemente, y sin remedio, la percepción de todo aquello que nos rodea.

C. M. R. Esta pregunta tiene que ver con lo anterior: ante el desarrollo hipercapitalista, la exacerbación de las industrias del ocio, la homogeneización cultural, la gentrificación y, lo que Pasolini llamó «la desaparición de las luciérnagas», siempre me surge una profunda inquietud, y es cómo buscar esos reductos de paganismo sin caer a nuestra vez en la más perversa forma de convertirlos en objeto simbólico de consumo, en parque temático o pose decadente. Pasolini no hablaba de paganismo sino de barbarie, y muchos le tacharon de decadente, y es que realmente encuentro muy problemático defender una postura intelectual y vital que consista en defender formas de vida que los propios individuos quieren abandonar, o cuya pérdida trae consigo, sí, un vacío irreparable pero otras ventajas indudables. Te pongo un ejemplo: hace poco volví a Bilbao después de no haber regresado desde comienzos de los años $90 \ldots$ Y en el Casco viejo no vi ni rastro de lo que antes era el paisaje habitual: pintadas, carteles, herriko tabernas... en lugar de las pancartas «Euskal presoak...» había «Welcome refugees» y donde antes había herriko tabernas ahora había cafés hipster pintados de verde piscina, pastelerías de cup cakes sin gluten... Y tuve la sensación de que se había ganado algo y perdido algo, sin lograr decidirme por cuál fuese el saldo final de la operación. Cuando voy a Lisboa y compruebo que cada pocos meses ha desaparecido alguno de sus comercios tradicionales de tejidos o ultramarinos, o alguno de sus cafés, sustituido por otro que lo «remeda», en un simulacro a veces muy fiel o incluso mejorado... no sé qué pensar, porque la nostalgia me lleva a aborrecer esa pérdida de las luciérnagas, pero sé que la acompañan indudables mejoras urbanísticas...

L. D. V. La «sociedad líquida» de la que hablaba Zygmunt Bauman no ha hecho sino acrecentar sentimientos de nostalgia respecto al pasado de modo algo parecido, 
pero desde luego paralelo, a como la «globalización», y especialmente el «globalismo», en cuanto a ideología de lo global o globalidad ideologizada, ha estimulado reacciones en clave local, regional y nacional. Lo que está siendo muy fácilmente apreciable en Europa, donde los demonios nacionales y nacionalistas nunca parece que se aplacarán del todo, a pesar de los avances del europeísmo en las últimas décadas. Y fue Bauman también quien confirmó que la falta de confianza en el futuro y, más exactamente, el descreimiento a propósito de la continuación del progreso en él, habría traído consigo una verdadera explosión de «retrotopías». Lo que, según se apreciaba en muchos de los relatos populares denominados «leyendas urbanas» (y que en realidad son nuestras leyendas contemporáneas), muestra un desencanto colectivo hacia el porvenir y, por ejemplo, un recelo profundo en torno a las innovaciones tecnológicas. La inclinación nostálgica por el ayer viene, no obstante, de lejos. Y generalmente está relacionada con transformaciones abruptas de la sociedad. Pensemos, ya que mencionas los cambios acaecidos en el casco viejo de Bilbao en los últimos años, en cómo fue en las áreas más prontamente industrializadas de España, como Cataluña y el País Vasco, donde antes tendió a idealizarse un pasado rural, mitificándolo, y a convertirlo, mediante el rescate y sacralización de sus «tradiciones», en un receptáculo de esencias y en un referente étnico para toda clase de reivindicaciones políticas o territoriales. Cuando en las últimas décadas Bilbao se des-industrializa con una reconversión forzosa, y forzada en buena medida desde Europa, tiene que inventarse. Y se centra, con notable éxito, en erigirse como capital cultural y artística relacionada con la idea de vanguardia: ahí está el Museo Guggenheim como baluarte y símbolo de tal cambio. Que aquello que estaba vivo, según sucede sobre todo con la cultura entendida como «inmaterial», pase a reciclarse como parque temático es casi inevitable en este contexto de movilidades líquidas. Y aunque las «luciérnagas» más visibles se apaguen o se remeden con focos led, sigue habiendo siempre otras luces que perviven justamente por pasar desapercibidas.

C. M. R. Tu trabajo para dar a conocer el cancionero de la Guerra Civil ha sido un modelo, y tanto en un nivel especializado como en uno, a su vez, «popular», ya que tus estudios no se quedaron en los círculos de expertos, sino que lograron trascenderlos y devolver al pueblo esas canciones. Pese al tiempo transcurrido, creo que es un trabajo de plena actualidad, por el siguiente motivo. Algunas de estas canciones (de las del bando republicano) han seguido funcionando como himnos y siendo cantadas por grupos de rock o punk (como Reincidentes o Los muertos de Cristo), lo que en cierta forma resulta, o me lo parece a mí, esperable y coherente. Pero en los últimos años hemos visto cómo «Bella ciao» se ha convertido en una canción coreada por los adolescentes que siguen la serie televisiva La casa de papel, o cómo en el Proyecto «Suena Guernica» Vetusta Morla hace una versión hipster de «Puente de los franceses» (https://www.youtube.com/ watch? $v=z r Q z B 39 U j x M)$. Y mi primer impulso es decir con firmeza : «No era esto». Sin embargo, ahí está...

L. D. V. También «era (y es) esto». «Bella Ciao», la mítica canción de los guerrilleros italianos, se ha popularizado ahora entre los jóvenes como banda de una serie televisiva. Y ha sido algo suficientemente demostrado ya, al menos para mí, por investigadores competentes, que lo que conocemos como el corrido más «tradicional»o las «tradicionalísimas» canciones sefardíes deben mucho de su constitución y expansión en cuanto género o expresiones reconocibles a la recopilación de cancioneros manuscritos, así como a la difusión de sus temas en pliegos impresos, pero tanto o más que a ello, a su circulación en grabaciones discográficas tempranas. Incluso algunas de las composiciones que llegaron a hacerse más populares en el bando republicano son, sobre todo, el resultado 
de las letras que autores muy cultivados de la Alianza de Escritores Antifascistas pusieron a las Canciones populares antiguas que García Lorca había grabado acompañando al piano a «La Argentinita», antes de la contienda. Porque la imbricación de Lorca en lo popular no tenía nada de provincianismo casticista, de vindicación de «lo propio por nuestro». Consistía en abrir a lo universal el legado recibido, innovar y esforzarse por comprender el mágico y misterioso canto del marinero que aparece en el «Romance del Conde Arnaldos». Y aprender esa canción solo al alcance de los que viajan en el barco del verdadero y único arte. Pues es muy de destacar que Lorca no se viera condicionado en su aproximación a tal conjunto de expresiones «del pueblo» por posturas preconcebidas respecto a la creación popular ni por la supuesta «autenticidad» de la misma o sus diferencias con lo «tradicional». Por el contrario, Federico García Lorca transitará sin apenas barreras y libremente en varias direcciones, reinventando todo lo que le pueda servir para hallar inspiración. Y eso fue lo que hizo posible que lo que él había tomado de un determinado acervo folklórico volviera a él...

C. M. R. Has sido uno de los autores que antes vio el interés del campo de las leyendas urbanas... En el presente, asistimos a la popularización de un género como el creepypasta, la divulgación de relatos de terror en formato vídeo en Youtube que después generan libros... En muchos de esos relatos persisten temas que ya aparecen en los índices de motivos folklóricos, pero muchos añaden un elemento de reflexión, no necesariamente crítico ni explícito o incluso consciente, sobre los propios mecanismos de transmisión actuales. Por ejemplo, sobre las evidencias fotográficas o los vídeos como (dudosa) prueba de verdad... Además, muchas de esas leyendas siguen teniendo como protagonistas a los lobos, aunque de una manera estilizada, con ilustraciones inspiradas en el manga japonés, una parafernalia entre gótica y hollywoodiense... ¿Es nostalgia, es una anulación total del valor de estos elementos en la tradición, o una renovación de la misma?

L. D. V. Decía Antonio Gramsci, a quien he tenido siempre como referencia y guía en mis investigaciones sobre cultura popular, que ésta puede ser entendida y rescatada en sus aspectos más conservadores, y a veces hasta reaccionarios, de reliquia y eco del pasado, pero que también lleva en sí una potencialidad subversiva y transformadora: la que a él y a quienes seguimos sus luminosas, aunque breves, apreciaciones al respecto, precisamente nos interesa más. Entiendo como «cultura popular» lo que antropológicamente entendemos por «cultura», una cultura de la gente y para la gente, no sólo de los «cultos» o de los artistas e intelectuales que encarnan la cultura hegemónica. Y lo que es más importante y revolucionario: creo que la gente, los grupos humanos, crean y transmiten cultura y arte, que cada individuo tiene capacidad de crear y de disfrutar las creaciones humanas como parte de un gran relato humano. Y que nadie debería negarle ni esconderle ese derecho. El derecho y la capacidad que nos han hecho la especie que somos. Por eso me ha interesado e interesa la cultura llamada popular y la antropología como proyecto humanizador de una humanidad siempre mejorable en que, sin embargo, podamos encontrarnos y ayudarnos en la diversidad y las diferencias. Hago votos porque así sea y mejoremos un poco todos, desde nuestra pequeña parcela, este mundo cada vez más preocupante. Un mundo donde crece sin parar el número de gentes obligadas a vagar sin rumbo tras haber sufrido toda clase de guerras, desastres y naufragios.

C. M. R. En Miedos de hoy tú planteas las actuales narraciones que circulan (a veces dejando entrever su condición de relatos inventados pero muchas veces con intentos de «garantizar» su veracidad) como manifestaciones de la condición humana, del homo narrans... Pero también señalas que las manifestaciones de cultura y arte colectivo actual suelen poner en evidencia síntomas de esa triple pérdida de territorio, tiempo y 
memoria. Cuando me he acercado a algunas de esas manifestaciones, como las fanfictions (reescrituras amateur a partir de series televisivas, novelas de éxito, películas, cómics, etcétera...) me ha llamado siempre la atención cómo una manifestación literaria popular que en principio consideraríamos desenfadada, espontánea... muy rápidamente genera casuísticas, clasificaciones de género, etiquetas, un metadiscurso crítico... Yo interpreto esto como una especie de «nostalgia del canon»: ante la apertura total que parecen ofrecer estas formas libres de creación, paradójicamente reaccionamos echando en falta las preceptivas, pautas y clasificaciones.

L. D. V. Sí. Se intenta acercar la llamada «cultura popular» a cánones vigentes u ordinarios en «la cultura hegemónica», deglutirla y engullirla finalmente dentro de ella, aun si ese proceso que tiene algo de alquímico ha de realizarse mediante la aplicación de un canon que parece simétricamente opuesto al de «las obras cultas» $\mathrm{y}$ «de autor». O sea, haciendo depender la «autenticidad» de aquella otra cultura de lo que dictaminen unos expertos o «guardianes de la tradición» que someterán esos ítems valorables al filtro de que sean «anónimos», «orales», «intemporales», etc. Ya que lo que las élites suelen entender como «cultural», la cultura dominante es, o parece ser, ni más ni menos que un resumen o extracto reduccionista de la más amplia definición de cultura (como conjunto de saberes que una comunidad o grupo crean y se transmiten), la cual la antropología sí viene asumiendo. De ahí que cultura resulte a menudo reducida a «tradición» en ese ámbito. Porque, en principio, se gesta sin que nadie tenga que subvencionarla: ni élites, ni mecenas ni gobiernos o poderes políticos. Los mediadores, sin embargo, sí que fijan precios y ellos mismos cobran su peaje por reconvertir todo esto en material susceptible de «canonizarse». Traigo esta reflexión a colación porque estamos atravesando unos tiempos en que se atisba o revela que, por diferentes motivos o crisis, la cultura subvencionada va a tener serias dificultades para resultar sostenible en un futuro más bien próximo. Y lo hago a sabiendas de que se trata de un debate incómodo, pero que no se me entienda mal: porque no estoy diciendo que la cultura en su conjunto y derivaciones ha de ser abandonada a su suerte, pues ya las culturas acostumbran a arreglárselas sin nadie que las financie o tutele (como bien se demuestra estudiando su vertiente popular) para ir saliendo adelante. Lo que señalo es que, al tiempo que reivindicamos el apoyo debido y en igualdad de condiciones con otras industrias para las industrias culturales, habrá que conceder a las culturas y su conocimiento, sin que ningún poderoso nos tenga que regalar su disfrute, el papel «transformador» que les corresponde en el diseño de un futuro más humano. Cosa bastante esencial hoy en un mundo sin apenas anclajes ni rumbo claro.

C. M. R. En ese mismo libro nos haces reparar en que, pese a definirse generalmente las leyendas por su anclaje en un tiempo y un espacio en principio concretos, en las «leyendas» urbanas que circulan por la Red (la rata del Ganges, el riñón extirpado...) hay una pérdida de esa referencia espacio temporal, cada vez más intercambiable. Eso no aminora, creo, su eficacia (mis alumnos me cuentan leyendas «recicladas» desde los años 80 y las creen), pero a la vez puede que sí se estén creando otras localizaciones espacio-temporales cibernéticas: todas las leyendas y rumores sobre páginas que matan, que anuncian una desgracia... y el atractivo de relatarlas dando información sobre la fecha (iy la hora!) de mensajes, de modificación de archivos, de visita a sitios web... ¿no son de nuevo una forma, casi desesperada, de buscar la relocalización y la retemporalización? Muchas de esas leyendas de terror en la red que te mencionaba antes giran en torno a misteriosos archivos informáticos («Sonic.exe»), sobre videojuegos con efectos fatales... Parece la confirmación de que nuestra cultura ya ha asimilado por completo lo que todavía se siguen llamando «nuevas tecnologías» y a la vez la señal de que, si comienza a existir 
un folklore en torno a ellas, quizá ya es hora de dejar de llamarlas «nuevas tecnologías». Por otra parte me parece que el que surjan estas leyendas es también síntoma de una ansiedad por «humanizar» estas tecnologías, como si no fuesen lo bastante nuestras hasta que las convirtiésemos en carne de leyenda... O como si tratásemos, mediante relatos, de paliar esa falta de anclaje en el tiempo, en el espacio, en la comunidad y en la memoria que ha traído el mundo virtual, dotándolo de leyendas que tratan de desempeñar ese papel de anclaje...

L. D. V. Algunos fuimos, seguramente, demasiado optimistas saludando la llegada de Internet y la entrada a sus ignotos caminos como la oportunidad para transitar por un nuevo territorio donde la «creatividad popular» se expresaría libremente o la información y sus usos se democratizarían de forma paulatina e imparable. Se vio nada más lo bueno y, sin embargo, también iríamos descubriendo con el tiempo muchos aspectos perversos en la utilización del medio recién inaugurado: el control y manipulación de nuestros datos e intimidades, las falsas noticias deliberadamente difundidas, las extorsiones internáuticas, la peor comercialización y explotación del sexo o del cuerpo humanos, la indignidad planetaria. Pues tan terrible debe parecernos la aplicación de penas absolutamente desproporcionadas a lo que no puede considerarse sino «delitos de opinión», como dejar impunes a quienes difaman, calumnian y violentan la honorabilidad de otros por las redes. Aunque por lo general en tales narrativas «urbanas» (pero en todo caso de índole que podríamos considerar «popular»), se trate de temores viejos o conocidos, es como si siempre emergiera de las mismas un horror diferente, inédito hasta ahora, a lo que pueda ocurrir en el futuro, al mundo que está por llegar. Y esto sucede porque las «leyendas urbanas», como cultura popular que son, tienen en sí la capacidad de expresar los desasosiegos por los que atraviesa una sociedad en cada momento mucho más directamente de lo que suelen hacerlo las creaciones individuales. Los grupos o «folks» no solamente responden a los cambios, estímulos y agresiones con desconfianza, apego a lo ya conocido o temores respecto a lo que vendrá: también lo hacen con intuiciones que se expresan a través de esos relatos que no son de nadie y son de todos en cierta forma. Porque a cualquiera le resultaría verosímil y posible en un momento dado lo que se cuenta en ellos, por sorprendente o tremendo que sea. E incluso, quizá, por eso mismo.

C. M. R. Volviendo a ese triple desarraigo de territorio, tiempo y memoria, en la cultura popular que circula en Internet ¿hay otros indicios de una conciencia de esa pérdida, hay intentos de sustituirla de alguna manera? A mí me lo parecen, por ejemplo, los grupos que en redes sociales se dedican a reconstruir virtualmente lugares y tiempos perdidos (los años 80, las ciudades en épocas pasadas) compartiendo archivos sonoros, vídeos, y sobre todo fotografías. ¿Tú crees que eso puede lograr subsanar esa orfandad de la que hablas, o lo que ofrecen es un simulacro, un sucedáneo de vínculos...?

L. D. V. La pregunta acerca de la pérdida o desaparición, no tanto ya de esos comercios de Lisboa a que te referías con anterioridad, sino de lo que en ellos se hacía y vivía, es decir, de una manera de vender y comprar en proximidad, de conocerse y relacionarse, conduce a lo que quizá sea la pregunta fundamental que deberíamos hacernos ante esta problemática. Ya que nada resolvemos lamentando la «desaparición de las luciérnagas» o asumiendo sin reflexión que su pérdida «es una pena» pero también algo así como un precio inevitable que hay que pagar por el propio curso del progreso. Y esto es lo que buena parte del folklorismo ha escondido tras sus gritos de alarma y llamadas al rescate urgente de lo que se extinguía en una cultura: la asunción de que las expresiones convertidas en productos (con que sus agentes trajinan) no tienen otra salida que amontonarse en las vitrinas de unos museos denominados como etnográficos. 
Sin embargo, la «gran pregunta», que diría el poeta Blas de Otero, sigue entonces sin plantearse. Lo que debemos cuestionarnos es por qué todo lo que parece que «sobra» debe sobrar. O sea, si en un modelo de mundo más deseable para el futuro aquello que «va sobrando» no tiene de verdad ya función ni utilidad o su fin ha sido decretado por las exigencias de un específico tipo de desarrollo (más que de progreso) mundial.

C. M. R. Una de las grandes preguntas que formulas en Miedos de hoy es si la creatividad literaria puede ser colectiva. Me parece que la pregunta indaga en el fondo sobre nuestra condición finita, mortal y efímera, que condiciona nuestra perspectiva mínima sobre la inmensidad circular del tiempo. Por una parte, a pesar de que en los 70 se hablase de la muerte del autor, este está más vivo que nunca, e incluso en las narrativas populares que circulan en la red el uso del nickname revela una tensión entre la disolución en la colectividad y la reivindicación de lo individual. La exposición visual, fotográfica de los escritores es mayor que nunca (yo a veces he pensado en escribir un ensayo sobre la pose del escritor, sobre todo desde el siglo XIX hasta hoy...). Y la idea de que nuestro idiolecto, nuestra forma de escribir, es una forma de identificación tan precisa como el ADN redunda en ese fortalecimiento de la autoría individual. Pero, por otra parte, alejando un poco el zoom, me parece que el autor, el individuo, el yo... no son más que una coordenada espacio-temporal fortuita en la inmensidad, y que en torno de esa coordenada azarosa hemos desarrollado una especie de «mística de la conciencia», de modo que creemos en el «yo»y en el «autor», pero incluso las creaciones individuales más personales no son más que una gota en un caudal colectivo... Sin embargo, repetimos que la cultura occidental es fundamentalmente individual... ¿lo era y ha habido un cambio, lo sigue siendo, no lo fue nunca tanto como creíamos...?

L. D. V. ¿Qué cultura occidental? La de «los cultos», posiblemente. Hubo que inventarse a Homero, a un «Homero», el «primer Homero», para fijar el canon por el que parecería que había de regirse la obsesión «autoral» de esa cultura en su vertiente más elitista. Pero en la base de esa misma cultura occidental encontramos que Homero eran varios, más que probablemente un «sujeto colectivo», y que es en la Odisea (otra obra atribuida a él) donde Ulises le dice a Polifemo que su nombre es «nadie». Ese «nadie» que podemos ser todos, ese «pueblo»o, mejor, ese «folk» que, como decía mi maestro Alan Dundes, desde su cátedra de folklore en Berkeley, «somos también nosotros», encarna y sirve para identificar muy bien la importancia del anonimato, que no es otra cosa que «creación colectiva» desde la raíz o el principio de nuestras culturas en Occidente. Me parece más interesante y fecundo replantearnos esto que proseguir con el debate estéril y enconado entre individualistas y tradicionalistas en torno a la épica o la balada. Enseña bastante, por sus paradojas de este tipo, el movimiento «folk» estadounidense de los años 60, a la luz de la revisión crítica que hacen de él los hermanos Cohen en una inteligente película, Inside Llewin Davis. ¿Y ello por qué? Porque esta corriente de aproximación a una cultura que se identificaba como popular, de la gente o del pueblo, por parte de jóvenes urbanos desarraigados (por ejemplo Bob Dylan o Dave Van Ronk), incurría, tal y como certeramente apuntan los Cohen, en algunas interesantes contradicciones. Recrean baladas irlandesas pero proceden de ciudades prefabricadas y ámbitos industriales, son, como diría con sagacidad Van Ronk, «neo-étnicos». Y gente «de izquierdas» que, sin embargo, no tenía muy claro cómo actuar para que el uso de la cultura y, más en concreto, de la cultura popular no reprodujera los mecanismos que conducían a la utilización de lo cultural como herramienta o arma del poder. Es decir, no acabara convirtiéndose en lo que Gramsci había denominado «cultura hegemónica» o de las élites dominantes. Esa contradicción sigue existiendo y no afecta solo, aunque quizá se haga más evidente, al 
tratamiento de la cultura popular: de hecho, con frecuencia se invoca desde la izquierda a la cultura, casi como elemento redentor, cuando aquello que finalmente ha sido sacralizado como hito cultural difícilmente escapa a las luchas de poder que determinan la cultura que ha de guardarse, conservarse o predominar. En parte, esto sucede porque la aproximación antropológica a la cultura que tiene mucho que ver con esos supuestos a que me refería al principio tarda en calar en este país y muchos otros de Europa, se confunde demasiado a menudo cultura con instrucción o educación y no se deslinda lo que es cultura, entendida antropológicamente, de la industria o industrias culturales masivas y no «artesanales». En este sentido, no puede dejar de recordarse el largo y accidentado camino de conceptualización de lo popular desde la Guerra Civil hasta el presente. Pues no es seguramente nada casual que quienes más apostaron, ya entonces como hoy, por la versión casticista y fosilizada del pueblo (para su manipulación) suelan recurrir a la tradición en cuanto estrategia de domesticación de lo popular: es decir, a modo de método reduccionista por el que las formas de vivir, pensar y crear de unas gentes quedan resumidas en sus tradiciones, muchas veces modificadas o reinventadas por los que dicen pretender salvarlas, guardarlas o defenderlas. De ahí que algunos colegas pensaran que mi libro Los guardianes de la tradición mantenía plenamente su vigencia e insistieran en reeditarlo, lo que al final hemos hecho en diciembre de 2019 con doble publicación en España y México.

C. M. R. Volvamos a los lobos: tanto en El regreso de los lobos como en Miedos de hoy apuntas a la persistencia de la oposición entre lo salvaje y lo doméstico o, más bien, lo domesticado, emblemáticamente encarnada en el perro/el lobo. Y señalas cómo sigue presente, de manera semioculta, subrepticia, en nuestros «mitos». A mí me resultó muy llamativa la forma en que los medios de comunicación y las redes sociales cubrieron el suceso de la violación múltiple de Pamplona. Titulares como «Caperucita y los cinco lobos feroces», «No fue un lobo, fue una manada», o viñetas parecidas al respecto ¿no son algo más que una referencia literaria empleada como recurso retórico, no nos hablan de una persistencia del cuento tradicional, que incluso hoy en día mantendría, más allá de ser un cuento, un cierto valor de «mito», de explicación de algo que rebasa o perturba demasiado a la razón?

L. D. V. Entre otras cuestiones que me formulo en esos textos hay un tema de fondo que tiene que ver con esto: más allá de la identificación en nuestro imaginario del «lobo», tanto en la cultura popular como en la que no lo es, con un «otro» como enemigo, con la fiereza y con lo salvaje o indomesticado, ¿qué debemos a ese rival y finalmente «compañero» en la evolución humana? Hay teorías de las que no vamos a tratar que van en el sentido de que la alianza entre lobos y humanos, que confluye en la construcción o «fabricación» genética pero también cultural del perro, un animal que no existía antes, favoreció e incrementó la expansión de los humanos por distintas zonas del planeta y, probablemente, también aceleró los efectos negativos sobre el medio que ocupaban, al esquilmarlo y degradarlo con más rapidez. De ahí procede seguramente cierta fascinación hacia el lobo-perro por nuestra parte, de la que no está exenta ni siquiera la corriente de opinión más negativa: en la «demonización» de algo subyace, muchas veces, una mitificación. Esa acepción satanizadora y marcada por un temor atávico respecto al animal es la que ha vuelto a servir para calificar una forma tan repugnante como cobarde de ataque hacia una «presa» que se presume fácil y en inferioridad de condiciones. Tiene su «coherencia metafórica» que se haga, pero, para no volver a «estigmatizar» al lobo, habría siempre que recordar dos cosas que se olvidan con demasiada frecuencia: una, que los perros que nos acompañan como inofensivas mascotas siguen siendo en una 
proporción genética apabullante «lobos»; dos, son rarísimas y discutibles las ocasiones en que se sepa que los lobos hayan atacado a los humanos, si bien alguna muestra literaria no comprobada habría de ello, por ejemplo, entre los romances de ciego. En El regreso de los lobos se recoge esa cierta ambivalencia del lobo como metáfora, en cuanto parte «salvaje» pero noble e inteligente de nosotros mismos que se resiste a desaparecer ante lo que, en clave marcusiana (Marcuse, 2010), podría interpretarse como la probable imposición de una civilización excesivamente tecnificada. De otro lado, estaría la realidad de la proliferación y regreso a nuestro mundo de «manadas» de todo tipo, literales y figuradas.

C. M. R. Aunque este debate se ha banalizado mucho, reduciéndose casi a una confrontación generacional, el mundo literario lleva ya años asistiendo a polémicas por los llamados «poetas de Twitter», surgidos al amparo de las redes sociales... El dictamen de muchos autores consagrados es que eso «no es poesía»... Yo no estoy tan segura de que no lo sea, pero me parece que se superponen al menos dos debates: uno sobre la creación poética y otro sobre el reconocimiento público del individuo al que se identifica como poeta...

L. D. V. Sí. Hay un aspecto del fenómeno, relacionado con el arte como cosa colectiva, que me atrae e interesa mucho: es la convicción de que todos los humanos, por serlo, tenemos la capacidad de crear, de expresarnos creativamente. Supongo que se trata de algo que tiene bastante que ver, además, con lo mismo que antes comentábamos a propósito de ese momento en que la cultura popular (las leyendas y chistes folklóricos, por ejemplo) entran, y se actualizan o multiplican, en Internet, en los ámbitos aparentemente libres del ciberespacio. Realidad, la de ese «netlore» que se estaba reinventando a sí mismo en las redes, que me movió a intentar averiguar cómo, por qué y para qué se estaba produciendo. Y, según ya apunté antes, con ese bagaje de lo que sabía, por haber venido trabajando durante décadas sobre los géneros más convencionales del folklore, di una suerte de salto en el vacío, siguiendo de cerca tal explosión de creatividad: así surge El regreso de los lobos. Ahora tenemos que adolescentes y jóvenes tienen el medio y el altavoz para expresarse como «poetas» o «ir de ello», igual que ocurría ya en épocas anteriores. No serán esa turba de jovenzuelos modernistas con revuelo de chalinas y fulares acerca de la que ironizaba Valle en algún pasaje de Luces de bohemia, porque no es la mera indumentaria la que los define (aunque también) sino, sobre todo, el que son «twitteros». A mí no me parece del todo mal. Saldrán de esto algunas creaciones y personalidades más o menos válidas y el resto volverá a ese Hades de olvido en que se sumergen tantas poesías juveniles de enamorados, tantos vates en ciernes escribiendo poemas de amor que eran, a la postre, más enamorados que poetas. Sin embargo, la propia ruptura con la idea desde hace siglos imperante de que el creador, el «artista», es solamente aquel devotamente entregado a serlo y consagrado por las élites como tal, en razón de sus obras maestras, me resulta en sí un hecho más que sugerente y acerca del cual vale la pena reflexionar y debatir. Puesto que la figura de «artista», concebida como autor o genio «único» que surge en el Renacimiento y se acaba reinventando o consolidando en el Romanticismo, actúa negativamente sobre otras muchas posibilidades de ser creador. En España, además, el franquismo instituyó un sistema de funcionamiento y manejo de lo cultural que no ha cejado. De manera que quienes son reconocidos y consagrados como «grandes artistas» lo son, particularmente, por la influencia de los poderes políticos.

C. M. R. Me gustaría aquí marcar un punto de inflexión en esta charla, e interpelar ahora al creador, poeta, novelista. Tú has reivindicado la dimensión personal y creativa de tu escritura como una parte fundamental e inseparable de tu trabajo investigador del 
antropólogo. ¿Admitir ese componente de creación es la única manera de construir un conocimiento consciente de sus límites y de sus aportaciones, y por tanto crítico?

L. D. V. Admitir ese componente creo que ayuda a ser crítico con lo que uno mismo escribe desde el primer momento. De un lado, porque obliga a que la escritura profesional o científica se resuelva del modo más cuidado, eficaz y podría decirse que hasta «hermoso». No se trata de escribir «bonito» o de la forma que algunos siguen pensando que el escribir es o cómo se vuelve más literario. Se trata de transmitir lo que se quiere decir de la mejor manera, que, en mi opinión, suele ser la más perfecta o bella. Tengo muy presente siempre, en este sentido, lo que decía Clifford Geertz respecto a la calidad de «autor»o «escritor» del antropólogo como parte fundamental de su trabajo y cómo el tiempo de una escritura roma y aséptica, o sacrificada a una pretendida objetividad, tenía que darse por concluido. Por mi parte, hace ya mucho que he procurado crear una especie de circuito de vasos comunicantes entre poesía, narrativa de ficción, ensayo, investigación. Y lo que no encaja plenamente en alguno de esos apartados es lo que, al fin, acaba nutriendo mis novelas.

C. M. R. Sin embargo, la comunidad científica, está cada vez más sometida a sistemas de calificación de los trabajos basados en el número de citas, rankings de editoriales y revistas, y eso deja poco espacio para integrar creación, pensamiento y discurso academicista... ¿Qué opinión tienes al respecto? Para mí, lo peor es que se ha hecho, y probablemente en un alto porcentaje bona fide, desde la propia comunidad científica, para frenar la endogamia, la laxitud de las valoraciones en baremos de plazas, etc. ¿No es eso especialmente perverso, no termina favoreciendo precisamente lo que trataba de evitar? Y otra pregunta en relación con la situación de la universidad: tú cuentas con la experiencia del mundo anglosajón, con la antropología estadounidense, pero ¿no crees que hay una excesiva pleitesía de nuestras universidades al inglés como lengua científica, cuando en la UE hay unas lenguas romances extraordinariamente próximas y que inexplicablemente cada vez conocemos menos? Yo no sé porque para publicar un artículo se nos pide el abstract en inglés y no en inglés o en alguna de las lenguas romances, algo que no sería un esfuerzo tan grande...

L. D. V. De acuerdo en que está sucediendo así. Y en ciertos aspectos es una lástima. Está bien que haya controles o evaluaciones con carácter general, de los que se conocen las reglas. En ese sentido, estoy convencido de que la evaluación de sexenios, que desde hace más tiempo que en la universidad era aplicado de facto en el CSIC para tener opción de promocionar a los distintos niveles de investigación, es una práctica recomendable. No lo estoy tanto de que la modificación del sistema de concurso-oposición libre hasta casi trocarlo en otra cosa, o los modelos copiados de las universidades norteamericanas, sean la mejor solución. Por mi parte, he procurado adaptarme a las «formas» y cumplir los requisitos que la trayectoria académica exigía administrativamente en cada momento, pero no vivido y trabajado o publicado para eso. Considero, no obstante, que la imposición de sistemas principalmente cuantitativos con criterios que, no por nada, han resultado muy polémicos (así la no computación de lo publicado en las propias instituciones) puede favorecer el reconocimiento de una «excelencia» que no resulta difícil de falsificar, fabricar, trucar. Incluso me parece que estos sistemas desembocan en la práctica acrítica de determinadas fórmulas o recetas «de éxito»: así, trabajar sobre temas o bajo advocaciones de etiquetas que se ponen de moda; y el responder a modelos reconocibles o aceptados ya desde la tesis doctoral acerca de lo que es o no una disciplina. Lo que, por ejemplo, en el campo de antropología, era asunto más abierto cuando los antropólogos de mi generación en España llegábamos de campos de formación distintos y éramos realmente 
interdisciplinares, además de insaciablemente curiosos. Y en lo que toca a esa especie de «tiranía del inglés» para todo, solo decir que en lo que me concierne he abogado en más de una ocasión y caso, por ejemplo en procesos selectivos donde la concesión de becas se ajustaba a un determinado grado de conocimiento del inglés como condición excluyente, por el que junto a él hubiera lenguas que igualmente sirvieran para alcanzar el certificado de aptitud a los aspirantes.

C. M. R. En 2011 Kenneth Goldsmith publicó Uncreative Writing, y en ese mismo año vio la luz Against expression, antología realizada por el propio Goldsmith junto con Craig Dworkin. Esta corriente conceptualista plantea la creatividad artística y literaria como una dinámica de apropiacionismo y repetición, recontextualización, corta y pega... Me parece procedente recordarlo en este nuevo contexto de las redes sociales, que permiten una transmisión («viralidad») no solo muy rápida sino también plásticamente visible y rastreable; sin embargo, creo que no es muy distinto de la idea de intertextualidad según la planteaban los postestructuralistas (para quienes la literatura es una combinatoria de palabras siempre ya dichas), y que tanto esta noción postestrucuralista como la formulación de la non creative writing no son sino maneras de expresar bajo un nuevo lenguaje la tensión entre repetición y creatividad que es consustancial a toda creación artística y toda tradición, en el sentido más amplio de la palabra.

L. D. V. Así es. Y todo ello está muy presente en el proceso de creatividad colectiva todavía negada por muchos pero que es lo único que explica la existencia de la cultura y el lenguaje, tan estrechamente ligados entre sí. Volvamos a lo que sabemos, por la recopilación y estudio en el pasado de nuestra cultura popular, y a un ejemplo singularísimo pero muy revelador que ya apareció previamente en estas conversaciones, el de la obra lorquiana más cercana a la «tradición popular». El logro de Lorca está en la comprensión cabal y el uso siempre arriesgado de dos tradiciones, las que suelen identificase con lo culto y lo popular, con la baja y la alta cultura, que prefieren decir algunos. Para hacerlo hay que disfrutar de su conocimiento, en una primera instancia, pero tan importante como ello será no pensar que una y otra tradición se encuentran irremisiblemente separadas, oponiéndose. Y hallarse en una posición de cierta equidistancia respecto a las ideas de «tradición»y «vanguardia», de modo que se propicie su interinfluencia. O se relativice su pretendido prestigio, desmontándose la mitificación que ambas cosas han llegado a alcanzar entre muchos «intelectuales y artistas». Para situarse en esa posición a un tiempo incómoda (por lúcida) y privilegiada (por lejana de la más habitual), Lorca tenía que partir de unas vivencias directas de la cultura popular, declaradas por él mismo en distintas ocasiones. Ese aprendizaje infantil, entre criadas y gentes del campo, de una cultura no letrada, no escrita, transmitida oralmente, le habría ayudado de forma inestimable a ser el tipo de poeta que consiguió ser. Y, de otro lado, también resultaría fundamental el acceso, disponible ya entonces para estudiantes y estudiosos cultivados, a las recopilaciones que iban siendo sistemáticamente acumuladas por filólogos y coleccionistas del acervo «folk» de diversas regiones. Como un verdadero pionero del camino que muchos recorrerán después de él, va a rememorar los cantos que escuchó de niño, coleccionará composiciones, espigará entre cancioneros y romanceros de índole popular piezas a las cuales arreglar e interpretar de nuevo, conforme hizo acompañando al piano a Encarnación López, «La Argentinita», en la famosa grabación de Canciones populares antiguas a la que ya he aludido. Y cuando él se adentre en los veneros del folklore hispano nunca «hará ascos» a lo que tantos compiladores tildarían de «vulgar», sino que escogerá sus motivos entre los romances de bandoleros y proscritos que muchos compiladores habían despreciado y seguirían despreciando más adelante. Un romancero conocido y recreado por unas masas 
populares contemporáneas, que si bien recibió adjetivos más bien peyorativos, en el siglo anterior, de su admirado Agustín Durán, sería ampliamente recogido por este, hallándose en viva transformación a principios del siglo XX...

C. M. R. Javier Cabornero, en el «Epílogo» que escribió para En honor de la quimera, libro que reúne (casi) toda tu poesía hasta 2015, dice algo que me parece muy acertado, y es que eres un humanista, como lo eran aquellos hombres del Renacimiento, no en el sentido de que hayas expresado tu conocimiento o tu capacidad creativa y expresiva en disciplinas y ámbitos distintos (ensayo académico bajo diferentes etiquetas, poesía, narrativa, teatro, música, pintura), sino en que todo ello obedece a un intento de (cito a Cabornero) «unir todos los cabos posibles para el entendimiento del hombre y del mundo», y a los hombres entre sí en «una hermandad en lo creativo», que tiene además como centro la palabra, al igual que lo fue para los humanistas, por ser lo distintivo y esencial humano. ¿Has entendido siempre como formas necesariamente vinculadas la vertiente investigadora y académica y la creadora, o esa coherencia ha sido un proceso?

L.D. V. No, en realidad me hallevado años de trabajo, dudas y afanes. Prácticamente, toda una vida. Y es más: durante bastante tiempo me esforcé en separar unas actividades de otras, e incluso vigilé que mi dedicación a unos campos no "contaminara» a lo que hacía en otros. Y llegué a la conclusión de que era una tontería. Y que lo mejor que podría hacer es dejar que lo descubierto o aprendido en una y otras vertientes se retroalimentara, que la imaginación se nutriera de reflexión y al revés. Lo hice siendo muy consciente de los riesgos. $\mathrm{Si}$, por ejemplo, fui durante bastantes años discreto y pudoroso con mis pasiones más creativas no negaré que actué de esa manera en la medida que entregarse a tales asuntos en el ámbito académico podía ser tomado como distracción o veleidad nada recomendables. Poco a poco, mi angustia en relación con todo ello desapareció, a lo que me ayudaría el constatar cuántos antropólogos y filólogos han cultivado (en vez de rechazar) su inclinación a la creación literaria y artística. Y entendí e intenté manejar de una manera positiva lo que ambos mundos me aportaban. Creo que pasó la época de negarle a uno mismo sus otras capacidades. Es más, creo que el mundo ha cambiado y que estamos entrando en una época en la que todo lo que es saber o resultar capaces de hacer algo que no sabíamos ni hacíamos no resta, sino que suma. Constituye un «valor añadido», no ya para nuestro currículum, que sería lo de menos, sino para una mejor supervivencia.

C. M. R. Tu obra poética se inicia con un tono angustiado y con la constante presencia de la muerte, la soledad y la sombra. Incluso la recurrencia de estos términos, literalmente, es muy alta en tus libros. A medida que avanzamos, y creo que especialmente a partir de En el umbral de Eleusis, esa presencia no decrece pero se hace más serena, como si efectivamente el acceso a una revelación terrible (como debía ser la de los misterios eleusinos, quizá el contemplar la propia muerte) condujese a la serenidad y a una mejor comprensión de la vida, una comprensión que ya no hace necesaria la trascendencia entendida como las religiones salvíficas la presentan, sino que queda satisfecha con la memoria como forma de encontrar cada hombre su lugar en la larga cadena de los hombres. Creo que también la necesidad de conversar con los muertos, o dejar que conversen entre ellos, presente en Los últimos paganos o Todas nuestras víctimas va por ahí...

L. D. V. Desde luego, pesa mucho en casi todo lo que escribo el misterio de la vida que puede persistir más allá de la desaparición de los cuerpos, bien por el amor que se depositó y aún nos profesan, incluso después de la muerte, otras personas, bien por la posibilidad de que haya para nosotros alguna clase de existencia ulterior. Mientras lleguemos a conocer algo más sobre esto, sí que podemos confiar y quizá hasta hallar 
cierto consuelo en que se puede vivir en otros, quedar en la memoria de los demás. Pero, de otra parte, también se plantea en estas relaciones e intercambios entre vivos y muertos otra cuestión de profundo calado antropológico: ¿qué se debe en nuestras vidas, en nuestras características, en nuestras inclinaciones, dotes o carencias, a herencia genética y a condicionamientos culturales? Ignoramos todavía demasiado sobre lo que una supuesta memoria genética, una especie de predisposiciones o ensoñaciones previas a nuestra existencia como individuos, con las que naceríamos, puedan incidir en lo que seremos y queramos ser. Y de esta amalgama de sueños de la sangre, de legados, de herencias, de estigmas, de destinos, nos han hablado siempre los mitos. No sé si las novelas citadas lo consiguen, aunque me gustaría.

C. M. R. Los últimos paganos, que resultó ganadora del Premio de Novela Ciudad de Salamanca en 2010, se anunciaba como la primera entrega de una trilogía dedicada a «Los mundos destruidos» y verdaderamente en esta narración asistimos a una recreación del testimonio de Antonio, último pagano en dos sentidos, pues es el habitante romano de un pagus que resiste el asedio de los cristianos, quienes impondrán una nueva manera de relacionarse con el mundo o, como tú señalas, «se arrogaron la licencia de reinventar el tiempo e inaugurar la historia». Yo diría que es una novela histórica porque recrea fielmente y no solo como telón de fondo un mundo (un mundo, por cierto, poco conocido, el de esa latinidad tardía que trasladaba a sus villas del campo el espíritu de una Roma que ya no existía más que en sus recuerdos o en sus relatos). Pero lo es también porque de esa manera habla del presente. Está muy claro en el siguiente pasaje:

En los palacios de los poderosos aún se amontonaban bellos libros, estatuas y objetos, cada vez ordenados con peor gusto. Legiones de cocineros preparaban extravagantes comidas de numerosísimos platos para los pocos que podían disfrutar de ese lujo. Los cargos públicos suponían un lastre económico que solo podían suportar los más ricos. Quienes vivían de los impuestos eran casi más que los que podían pagarlos. (Díaz Viana, 2010: 98).

Parece un retrato muy reconocible de nuestra sociedad, en detalles como la hipertrofia de cargos públicos o la desmedida atención a la cocina y la comida, como ejercicio de virtuosismo casi artístico, algo que parece un signo inequívoco de decadencia (es, de hecho, un signo literalmente escatológico)... En ese sentido, ¿cumple esta novela, pese a ser ficción novelesca, una parte de la función del mito, la de mostrar una verdad que afecta a los asuntos fundamentales de una comunidad: por ejemplo, nuestra relación con el pasado, necesitada, como tú dices, de museos, de novelas... que recuperen un vínculo con las generaciones que nos precedieron, según antes era natural, porque hoy se ha perdido?

L. D. V. Dice Catherine Nixey en La Edad de la Penumbra que «en un arrebato de destrucción nunca visto hasta entonces - y que dejó estupefactos a los muchos no cristianos que lo contemplaron-, durante los siglos IV y V la Iglesia cristiana demolió, destrozó y fundió una cantidad de obras de arte simplemente asombrosa» (Nixey, 201824-25). Lo que tiene mucho de real. Y que «se derribaron las estatuas clásicas de sus pedestales y se desfiguraron, profanaron y desmembraron. [...] Muchas de las esculturas del Partenón sufrieron daños; se les mutilaron las caras y las manos, se les arrancaron las extremidades y se decapitó a los dioses» (Nixey, 2018: 25). En ese libro, posterior a mi novela y a la obra de teatro que se deriva de ella, se dice algo bastante cierto, pero lo que allí se afirma y denuncia tampoco constituye toda la verdad de lo sucedido. Porque, al escribir 
desde una perspectiva anglosajona, Nixey no es consciente de que, contra lo que supone en ciertos párrafos de su obra, algo así como «el pálpito cultural del mundo antiguo» nunca desapareció del todo, que en las áreas de la Europa Mediterránea que constituían la romanidad se siguió hablando el latín vulgar, luego ramificado en distintos dialectos que se convertirían en nuestras lenguas romances, y que muchas creencias, costumbres, mitos y rituales pervivieron (muy especialmente en el medio rural). En realidad, y de ahí la actualidad de lo tratado en la novela, el derrumbe de aquella "globalidad romana» tiene muchas semejanzas y coincidencias con el tiempo que estamos viviendo. Casi todos los periodos de crisis de las civilizaciones conocidas por la historia las han tenido. Y la estrategia narrativa que cabía emplear era relacionar los sentimientos de temor, angustia e incertidumbre ante esas épocas de cambio desde la vida cotidiana, desde el oscuro existir de una Roma «de provincias». Seguramente no pensamos en todo como romanos, pero sí que sentimos y hablamos aún de manera muy parecida a ellos. Sí que resulta factible reconocernos en lo que vivieron. Y aprender de unos mitos que siguen siendo los nuestros. En ese aspecto, me gustaría que los lectores pensaran que la novela cumple tal función.

C. M. R. Hay, además, en la novela, una gran densidad de asuntos sobre los que se podría desarrollar un ensayo, muchos de los cuales tratas, de hecho, en tus trabajos académicos: la ruptura de una relación armónica con la vida, la muerte y la Naturaleza, la relación entre pensamiento y lenguaje, la sustitución del politeísmo por el monoteísmo y todo lo que este implicó... ¿Tratarlos en una novela es una forma de coherencia, de no plegarse a la división artificiosa de géneros y recurrir al relato como forma vital?

L. D. V. Se ha destacado ya en algunos comentarios a mi narrativa que lo que intento es una aproximación a la novela como género de géneros (yo diría «género total») en que lo poético, lo histórico y lo ensayístico buscan encontrar acomodo dentro de un mismo relato. Aunque no todas van a llevar un subtítulo, mi plan inicial era que cada obra lo tuviera y fuera uno en que se señalara el género convencional al cual el texto podría ser asignado. Así, Los últimos paganos se subtituló como La leyenda del fin del mundo; Todas nuestras víctimas iba a subtitularse Cuento para consuelo de fantasmas. Finalmente lo retiré, porque me pareció que resultaba preferible dejar el título sin más, ya muy rotundo de por sí, a causa de que adquiría mayor fuerza solo. Y la novela que hay en proyecto y que he empezado a escribir se subtitularía El mito de la civilización. Leyenda, cuento, mito. Tres géneros desbordados conscientemente en mis relatos pero que, además, provienen y tienen su origen en el campo de las literaturas populares para después pasar a la historia de la más culta.

C. M. R. Uno de los elementos que más me gustaron en la novela es un rasgo común con tu poesía o con una buena parte de ella (En el umbral de Eleusis, sobre todo): la recreación del pensamiento religioso romano: no de la religión oficial, sino de la práctica cotidiana y personal. En la novela hay una presencia y defensa de los dioses menores y liminares. Hay un pasaje muy hermoso en el que Antonio evoca la voz de Máximo diciendo lo siguiente:

Lo malo de quienes dicen creer en un solo Dios es que están convencidos de que ese Dios no puede ser más que el suyo. Los hombres para ellos no tienen importancia, pues sólo son las piezas de un cruel juego celestial. Y no volveremos, ya, a ser, si de ellos depende, los señores de nuestros actos, responsables de nuestra vida y con capacidad de elegir nuestra muerte. Amar a los dioses pequeños es respetar a todo lo que tiene vida. No es tanto creer en que hay espíritus en las montañas, faunos en las arboledas y ninfas en las aguas de los ríos o fuentes. Es sentir que hay vida en todo ello. No una vida única, 
limosna de un Dios absoluto y tiránico, sino vida diversa que crea complicadas armonías y a veces misteriosas estridencias. (Díaz Viana, 2010: 36).

La sustitución de una religión con un número amplio y abierto de divinidades por un monoteísmo de raíz hebrea trae consigo la idea de Poder absoluto (en Grecia y Roma Júpiter, Cronos, Urano... estaban muy lejos de serlo, como la mitología demuestra una y otra vez...) y por tanto de sumisión absoluta del Hombre a la divinidad, una divinidad que ya no se parece en nada a él y que de hecho es irrepresentable (aunque en Cristianismo paulino tratase de paliarlo en parte...) En otro pasaje, significativamente en verso, afirmas que el bosque es «[...] un lugar lleno de nombres. // De él nacieron todos los cuentos, / los dioses humildes / esos que susurran a los hombres el consuelo de la fantasía» (2010: 48). ¿Es esto la expresión de una confianza en la capacidad de la ficción para seguir canalizando la trascendencia del Hombre, toda vez que la religión no lo hace de manera satisfactoria?

L. D. V. Totalmente. Y en ello creo que sí se produce, tanto o más que una «coherencia» - que espero la haya - con aspectos que antes hemos comentado (por ejemplo en relación a la creatividad colectiva y mi indagación acerca de la cultura popular), un desarrollo a través de la ficción, o de un ensayo-ficción, de las mismas convicciones que han iluminado mi trabajo profesional de investigador. Y es que a menudo pienso que si me decanté por determinados temas desde muy pronto, como era el de esa creación colectiva en lo cultural, fue porque la creatividad humana, en sí, constituye uno de los asuntos que más me fascinan. De los que más quiero saber y aprender. De manera egoísta, porque a mi vez me siento especialmente vivo y humano efectuando un «acto de creación». Algunas apreciaciones de Jacques Le Goff, por un lado, y por otro Marc Augé en su libro El genio del paganismo, me pusieron en la pista de averiguar cómo habían funcionado las cosas dentro de lo que después hemos considerado «cultura popular» y descubrí esa continuidad de aquel mundo antiguo en nuestra vida y prácticas más cotidianas. El paganismo (al que también te has retrotraído al principio) permaneció, particularmente en el sur de Europa o, si se quiere, en la Europa mediterránea, en multitud de expresiones de la cultura popular. A mí me sorprendió sobremanera comprobar que las costumbres y ritos, a las que se refería Martín de Braga en su Sermón para los rústicos, yo los había podido seguir viendo practicar en mi infancia en el entorno del pueblo castellano donde viví mi infancia. Y esto nos lleva a un «descubrimiento del pueblo» del que se suele hablar poco y que precede al apuntado por Peter Burke en su famoso libro sobre La cultura popular en la Europa moderna a propósito del interés y atracción de los románticos por el folklore: me refiero al acercamiento que se da con el Renacimiento y los humanistas (significativamente italianos y españoles) a los conocimientos y costumbres identificados como «vulgares». Son ellos los primeros en rescatar saberes de la cultura popular porque interpretan que tales reliquias, no arqueológicas, sino inmateriales, consisten en restos (o ruinas también) de la Antigüedad que han llegado, directamente, hasta su época. Se trata de un campo apenas explorado al que creo deberían dedicarse muchas tesis doctorales de la universidad española, y desde diversas disciplinas, ya que ese «descubrimiento» temprano de nuestro humanismo es trasladable al presente, en el sentido de que todavía puede seguirse redescubriendo la huella del mundo grecolatino y el paganismo clásico en las culturas europeas del Mediterráneo, lo que evidentemente no ocurre en otros países de Europa donde la aproximación a la Antigüedad siempre se dio, por lo general, revisitando el mundo antigua a través de vías cultas y arqueológicas o librescas. 
C. M. R. Más tarde, a partir de tu primera novela, realizaste una versión teatral, Paganos. Yo leí la novela como un intento de trascender la mera ficción novelesca como la entendemos habitualmente, y encontrar en ella algo de mito, y en ese sentido me pareció muy coherente que desembocase en una pieza teatral, ¿es un teatro que mantiene algo del origen del género: lo ritual, la anagnórisis, la catarsis...?

L. D. V. Todo fue bastante casual. Pero yo no hubiera aceptado lo que surgió como un encargo concreto si no le hubiera encontrado, desde el primer momento, ese sentido. Todo el sentido que precisamente acabas de señalar. Porque siempre he tenido muy claro que con mis novelas quería acercarme a esa dimensión que tiene el mito de respuesta o nueva pregunta respecto a un misterio, de aproximación no racional pero plausible en su relato, como señalaban los Diálogos platónicos, al tenebroso campo de la pugna, tensión e intensidad entre opciones contrarias que el mito plantea si no pretende resolver. El teatro entonces, y por así decirlo, me esperaba (o aguardaba a mi relato) pues es, en su dimensión ritual, el escenario por antonomasia del mito. Aun sabiendo eso, no lo constaté del todo hasta que asistí, en la Villa Romana de Almenara, que es la que, además, dio pie a mi primera narración novelística, que Los últimos paganos era tanto drama como novela o, según yo mismo me he permitido bromear, una «tragedia tecnificada» (en la medida que el montaje incorpora videos que se proyectan y sobrios pero complejos efectos audiovisuales).

C. M. R. En Los últimos paganos hay una gran presencia de la poesía. No solo hay poemas insertos, sino que incluso en la prosa, en realidad, es posible encontrar versos y poemas incrustados, un pensamiento poético en torno a una alabanza del paganismo sumamente conmovedora: «Habíamos conseguido que el mundo pareciera casi en orden. Y, en cierto modo, perfecto. Quizá el paganismo sea solo una colección de fábulas, no sé si morales o inmorales, como llegó a escribir Agustín, el obispo de Hipona. Pero se trataba de una poesía que daba sentido a nuestras vidas» (2010: 49), «El cambio de Dios nos ha dejado a la intemperie, sin dioses conocidos, solos en el universo y rodeados de peligros» (2010: 67), «Ya estamos, en cierto modo, derrotados. Nuestro mundo está dejando de existir. Pocos creen en él. Nadie sabe lo que vendrá después. Luchamos contra lo que parece ya inevitable» (2010: 113). No encuentro en la literatura española muchos referentes a cuya estela se pueda acoger este pensamiento, fuera de Luis Alberto de Cuenca, quien precisamente prologa tu poesía reunida, pero cuya poética se sirve de un lenguaje muy diferente del tuyo. ¿Hay algún modelo que tú reconozcas en la novela, o autores actuales en narrativa y en poesía con quienes sientas una especial afinidad?

L. D. V. Algo en que he evitado incurrir es en la escritura de meras fábulas, ya fueran ideológicas o morales. Creo que son fatales para la literatura en general y la que yo procuro cultivar, en particular. En la fábula la respuesta, que existe previamente, resulta más importante que la pregunta. En la reutilización de mitos sucede al revés: la contestación que supuestamente nos da ese mito surgido de un mitologema anterior, responde al relato, a ese caso que se nos cuenta, de algún modo, sí, pero al hacerlo genera una infinidad de nuevas interrogantes. La conexión con Luis Alberto de Cuenca es muy acertada, sin duda. Porque, si bien pueden existir esas «diferencias de lenguaje», es mucho lo que compartimos al movernos ambos entre el mundo académico y el de la creación, mostrándonos apasionadamente deudores de los modelos literarios que nos legó la Antigüedad. Y convencidos de la actualidad que conservan muchos de ellos. En mis novelas publicadas puede apreciarse que las referencias que me han servido son variadas: Robert Graves, al que siempre he admirado como ensayista y poeta, es una de ellas; John Berger es el «culpable», entre otras resonancias suyas que no sería difícil encontrar, 
especialmente en mi segunda obra de ficción, de que en Todas nuestra víctimas me decidiera a incluir un ensayo final, sobre cuya pertinencia guardé reservas hasta el último instante. En el estilo, en la búsqueda casi desesperada de un «tono» y un «andamiaje» adecuado, por complejo que resulte, para lo que quiero contar, es António Lobo Antunes quien con probabilidad más influye en cómo quiero o me gustaría escribir. Y es que hay páginas suyas de verdad deslumbrantes, auténticos «misales» de la mejor literatura.

C. M. R. Un tema fundamental de tu obra de creación es la memoria, pero no entendida solo en el plano personal, sino en el intergeneracional: aquello que nos liga a los seres humanos que nos han precedido y a aquellos que nos seguirán, el hilo, por tanto, que nos sigue haciendo humanos, reconocibles en otros pese a los siglos que nos separan. En cierto modo, el paganismo de tu obra va también por ahí, como un intento de recuperar una comunicación con el pasado y con los muertos más natural que la que nos ha impuesto el Cristianismo. Creo que ese tema, y el peligro de perder esa memoria, aparecen expresados en tu obra con motivos recurrentes: el bosque como territorio primigenio o mundo anterior al mundo, el regreso a la casa (y el riesgo de extraviarse y no encontrar el retorno a ella), el perro (o el lobo) y lo que enseñan, en su convivencia, al humano, los pájaros y su canto, el accidente de coche... A veces estos motivos aparecen de manera casi idéntica de unos libros a otros, estableciendo puentes de comunicación entre los títulos, como pasadizos que hacen de ellos una única obra, rompiendo incluso los límites entre géneros... ¿Buscas deliberadamente tender esos puentes, con un proyecto de «obra total», o es algo espontáneo en lo que reparas después, en la lectura?

L. D. V. Creo que somos, fundamentalmente, un animal hecho de memoria y algo más. Y los paradigmas de tiempo, lugar y la memoria que los ligaba entre sí han cambiado bruscamente en los tiempos recientes. Pero yo creo que lo que más nos empobrece es tragarnos nuestros propios clichés o estereotipos acerca de nosotros mismos. O los que nos imponen desde fuera otros. Y me gustaría insistir una vez más en la importancia y utilidad de los estudios antropológicos en la construcción y gestión de la identidad cultural, por ejemplo, que es algo de tanta transcendencia en el desarrollo integral de los pueblos hoy en día, en tiempos de globalización. Y ser, así, conscientes y dueños en buena parte de nuestro propio relato identitario y evitar en lo posible que nos lo confeccionen ni adjudiquen otros... Yo, en efecto «he regresado». No únicamente porque vivo la mayor parte del año en el mismo paisaje en que crecí de niño. Mi retorno ha sido a unos recuerdos de infancia de los que he sacado la fuerza para afrontar las dificultades por las que he tenido que pasar. Y eso, efectivamente, lo aprendo con mis averiguaciones en unos y otros campos, con mis itinerarios personales entre creación y ciencia, pero — sobre todas las cosas - interconectando tales aprendizajes y recorriendo esos «pasadizos» y «puentes» en una y otra dirección. Mi mundo se compone de bosques, casas y perros muy concretos, muy reales, que he conocido, que me han enseñado. Y de la fortaleza que he podido encontrar en una infancia, si no feliz afortunada, que me legaron mis padres. Todo se completó cuando entendí que con sus creencias «no oficiales», con su religión íntima, que, sin que ellos lo supieran, también era, como la de sus vecinos en el mismo pueblo, más pagana que cristiana, podía perfectamente coincidir. Con todo, eso no lo descubrí hasta que murieron y fui a visitar su tumba.

C. M. R. En esa toma de partido por el paganismo como una forma de religión más humana que la judeocristiana me ha parecido que los personajes femeninos desempeñan un papel especial como depositarios del secreto frente al dogma... Carmen en Todas nuestras víctimas, Vétula en Los últimos paganos... ¿Crees que las mujeres, por haber 
estado durante siglos ligadas a la esfera del hogar y lo privado, han podido mantener mejor esa familiaridad con los ritos que se pierden?

L. D. V. Un asunto que me viene interesando mucho desde hace tiempo y sobre el que he ido reuniendo bastante material de todo tipo, aunque haya publicado solo algún artículo al respecto, es el del pensamiento mágico y, más en concreto, la brujería (y las particulares interconexiones dentro de ella entre lo «culto» y lo «popular»). No es que con ello pretenda seguir la senda que hizo célebre a quien reconozco como uno de mis maestros, Julio Caro Baroja, pero creo que con sus indagaciones sí tocó de cerca un gran tema antropológico sobre el que conviene continuar investigando: la marginalidad de la mujer sabia. Es el mito de Medea, por volver al mundo clásico, pero también el modelo de la mujer que - como bien señalas - conoce lo que no alcanzan a saber los demás, un secreto que puede estar muy cerca de nosotros, acechando...

C. M. R. Todas nuestras víctimas es un libro coral en el que se concitan las voces de varios narradores con puntos de vista opuestos, y con un fin que los iguala entre sí, y que además los iguala a las generaciones anteriores, con las que hay, sigue habiendo, cuentas pendientes. Pero junto a los narradores está también integrada la voz del autor, explícita en el ensayo final. ¿Responde a la necesidad de sumar ficción y no ficción para lograr una escritura que pueda lograr acercarse de algún modo a la realidad, que parece escapar siempre a nuestras palabras?

L. D. V. Por completo, sí: la narración aborda aparentemente el suicidio de un antiguo gerifalte franquista y el regreso algo misterioso de su hija a la casa familiar. El tema de los desaparecidos en la Guerra Civil y por el terrorismo. Pero hay mucho más. Porque esos sucesos hacen que se vayan desencadenando una serie de recuerdos y fantasmas familiares por parte de ella y de su hermano, a la sazón alcalde del pueblo castellano en que ambos nacieron. Se trata, por lo tanto, de una historia de familia como la de tantas otras familias españolas, pero contada aquí a varias voces por los miembros actuales y, en algunos casos, desaparecidos de la misma, en que de repente irrumpe con todo su impacto la ejecución de un atentado terrorista cuya autoría no acaba de dilucidarse. Es la segunda entrega de la trilogía iniciada sobre «Los mundos destruidos», junto con mi novela de Los últimos paganos. Y a diferencia de aquella, en que se indagaban hechos ocurridos en un pasado remoto, en esta narración lo que se cuenta llega hasta nuestro mismo presente. De ahí los ecos o alusiones algo nebulosas a lo que podrían ser los atentados del $11 \mathrm{M}$ en Madrid. Incluso, hay momentos en que el relato parece adentrarse en el territorio en sombra de un desconcertante futuro... el de nuestro país.

C. M. R. Aunque en este libro la memoria se manifiesta en la forma concreta de la memoria histórica, el abordar conjuntamente otro episodio con víctimas a las que se les niega en cierto modo la memoria, o se tergiversa ésta en función de intereses variopintos, como es el $11 \mathrm{M}$, creo que se universaliza el tema, ¿es así? ¿crees que ocurre especialmente en España?

L. D. V. Sí. Porque como explico en la «Nota aclaratoria» al final del libro, y también vengo a resumir en el «Sermón» que cierra el relato, «no es de la Guerra Civil ni de unos atentados concretos de lo que habla esta historia, sino de otras amenazas y otros terrores que aún nos acompañan o pueden estar por venir». Pues es la mía una novela sobre las cuentas pendientes con la memoria que aún tiene nuestra nación, pero también acerca de la necesidad de reconstruir para ella una casa o patria común en que puedan obtener el digno lugar y reconocimiento que les corresponde «todas nuestras víctimas». Tal reconciliación solo puede hacerse desde el rigor. Puesto que la inesperada proliferación, últimamente, de películas y libros que dan la impresión de buscar cierta 
clase de «conciliación» entre las dos (o distintas) Españas, por «light» que esta sea, puede sonar bien, pero también suscita alguna inquietud. Y es que cabe preguntarse si se está llegando a un reencuentro real o a un simulacro de él. Esa sería la cuestión que surge tras ver películas como Mientras dure la guerra, en que no pocos espectadores saldrán del cine cuestionándose si la aparente objetividad con que se nos presenta el inicio de la contienda incivil no enmascara, tras el revoloteo de banderas sucesivas, una deliberada confusión engañosamente neutral; si hay, o incluso es factible, sin dejar al lado la veracidad histórica, un reencuentro o conciliación reales. Hay dos aspectos que parecen chirriar en este sentido: la enseña que al fin ondea y prevalece es la que es, y no la otra a la que solo se ve flameando muy puntualmente; y los asesinados en las cunetas parecen estar durmiendo la siesta de un pícnic. Es decir, no hay nada cruento en el film, ni otro símbolo alternativo a la bandera que aún representa a la nación. Lo que me preocupa. Ya que no habrá de darse auténtica concordia si se relativiza o aligera la historia y no se cuenta lo que sucedió en toda su verdad. Por terrible que esta parezca. De la misma manera que el catastrofismo excesivo y la ausencia de equidad al encarar nuestro pasado nada ayudará para conocer la realidad de un país en lo bueno y malo. E incluso para amarlo o defenderlo sin excesos ni necesario ninguneo o desprestigio de otros. Digo esto, acordándome de que - como antes hemos recordado - mi obra, Canciones populares de la Guerra Civil, fue de las primeras en aproximarse, desde una mirada antropológica, a la pervivencia oral de las canciones de uno y otro bando. En un libro y una edición inicial del mismo, la de Taurus, que, si bien se difundió bastante, no dejaba de encontrarse, al ser presentado en algunas librerías o en la Biblioteca Nacional, con más de una reticencia. Ya que sí da a veces la impresión de que no somos conscientes de la carga pesada del franquismo que España arrastra prácticamente en todos los sectores de actividad y que provoca, por ejemplo, que se sigan prohibiendo canciones desde unas y otras facciones cuando ostentan el poder. Quizá a causa de que se instituyó durante los años de duración de aquel régimen un sistema parasitario y mafioso que, más que desaparecer, ha venido a refinarse o adoptar nuevas y sofisticadas formas de dominación. Lo que cabe apreciar en cómo se siguen haciendo muchos negocios, cómo se condiciona a veces el normal funcionamiento de las administraciones o se hace política no «desde» sino «con» eso que se sigue llamando «el mundo de la cultura». Un mundo teledirigido demasiado frecuentemente por el poder o poderes. Así, decidiéndose estratégicamente a quien se premia o consagra y a quiénes no; y qué es oportuno o no en lo político de acuerdo con el instante que se vive y las estrategias de la cúpula imperante. Todo eso habrá que tomarse muy en cuenta, también, porque no se puede pervivir sin memoria, sin conciliarnos y avenirnos con ella como país.

Valladolid, julio 2019-enero 2020

\section{BIBLIOGRAFÍA}

Augé, Marc (1993): El genio del paganismo, M. A. Galmarini Rodríguez (trad.), Barcelona, Muchnik.

BuRke, Peter (2014): La cultura popular en la Europa moderna, A. Feros, Sandra Chaparro (trads.), (3 ${ }^{\text {a }}$ ed.), Madrid, Alianza. DOI: <https://doi.org/10.1386/jepc.5.2.89_1>

CABornero, Javier (2015): «Epílogo», en En honor de la quimera. Poesía junta y revisada. Díaz Viana, Luis, Madrid, Devenir, pp. 259-297.

Díaz Viana, Luis (1986) (ed.): Canciones populares de la Guerra civil, Madrid, Taurus. 
Díaz Viana, Luis (1999): Los guardianes de la tradición. Ensayos sobre la «invención» de la cultura popular, Oiartzun, Sendoa.

Díaz Viana, Luis (2003): El regreso de los lobos. La respuesta de las culturas populares a la era de la globalización, Madrid, C.S.I.C.

DíAz Viana, Luis (2010): Los últimos paganos. Nivaria o la leyenda del fin del mundo, La Coruña, Ediciones del Viento.

Díaz Viana, Luis (2015): En honor de la quimera. Poesía junta y revisada, Madrid, Devenir.

Díaz Viana, Luis (2017): Miedos de hoy. Leyendas urbanas y otras pesadillas de la sobremodernidad, Salamanca, Amarante.

Díaz Viana, Luis (2018): Paganos, Valladolid, Páramo.

Díaz Viana, Luis (2018): Todas nuestras víctimas, Valladolid: Difácil / Páramo.

DíAZ VianA, Luis (2019): Los guardianes de la tradición ... y otras imposturas acerca de la cultura popular, Valladolid / México D.F., Páramo-LAN, Universidad Nacional Autónoma de México.

Goldsmith, Kenneth (2011): Uncreative writing. Managing Language in the Digital Age, New York, Columbia University Press.

Godsmith, Kenneth; Dworkin, Craig (2011) (eds.): Against expression. An Anthology of Conceptual Writing, Illinois, Northwest University Press.

Gramsci, Antonio (2013): Antología. Manuel Sacristán (sel., trad. y notas), Tres Cantos (Madrid), Akal

Hobsbawm, Eric; Ranger, Terence (1983) (eds.): The Invention of Tradition. Cambridge, Cambridge University Press.

Marcuse, Herbert (2010): Eros y civilización, Álvaro Pombo (pról.), Juan García Ponce (trad.), Barcelona, Ariel.

Nixey, Catherine (2018): La edad de la penumbra. Cómo el Cristianismo destruyó el mundo clásico. R. González Ferriz (trad.), Madrid, Taurus.

Fecha de recepción: 20 de enero de 2020

Fecha de aceptación: 24 de febrero de 2020

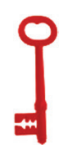

